\title{
DigitalPreservationCoalition
}

\section{Digital Preservation Coalition Rapid Assessment Model (DPC RAM)}

\section{Contents}

Document History

Overview 2

Origins and Acknowledgements $\quad 2$

Guiding Principles 3

How to Use This Model 3

Benefits of Use $\quad 4$

Benefits for DPC Members $\quad 4$

Explanation of Terms $\quad 5$

Note on Scope $\quad 5$

Comments, Feedback and Revisions $\quad 6$

$\begin{array}{ll}\text { The Model } & 7\end{array}$

Organizational capabilities $\quad 8$

A - Organizational viability 8

B - Policy and strategy 10

C - Legal basis 11

D - IT capability 12

E - Continuous improvement 13

F - Community 14

Service capabilities $\quad 15$

G - Acquisition, transfer and ingest 15

$\mathrm{H}$ - Bitstream preservation $\quad 17$

I - Content preservation 18

$\mathrm{J}$ - Metadata management 20

K - Discovery and access 21

Appendix I - DPC RAM worksheet $\quad 23$ 


\section{Document History}

\begin{tabular}{|l|l|l|}
\hline Version & Date & Revision notes \\
\hline 1 & $1^{\text {st }}$ September 2019 & First release of DPC RAM \\
\hline 2 & $31^{\text {st }}$ March 2021 & Revision of DPC RAM after community feedback \\
\hline & & \\
\hline
\end{tabular}

\section{Overview}

The Digital Preservation Coalition Rapid Assessment Model (DPC RAM) is a maturity modelling tool that has been designed to enable a rapid benchmarking of an organization's digital preservation capability whilst remaining agnostic to solutions and strategy. The model provides a set of organizational and service level capabilities that are rated on a simple and consistent set of maturity levels. It will enable organizations to monitor their progress as they develop and improve their preservation capability and infrastructure and to set future maturity goals.

Digital preservation is defined as the series of managed activities necessary to ensure continued access to digital materials for as long as necessary. It refers to all of the actions required to maintain access to digital materials beyond the limits of media failure or technological and organizational change. ${ }^{1}$

The model is freely available for anyone to use, but DPC Members will also be offered the opportunity to share their results and compare their progress with other members of the Coalition. This process will also help facilitate DPC Member Support activities, providing DPC staff with an efficient, continuous and standardized approach to capturing information on member needs and issues.

\section{Origins and Acknowledgements}

The model draws from an array of existing maturity models, and is primarily based on Adrian Brown's Digital Preservation Maturity Model ${ }^{2}$. It was also informed by the NDSA Levels of Preservation ${ }^{3}$, the Digital Preservation Capability Maturity Model $(\mathrm{DPCMM})^{4}$, the Assessing Organisational Readiness (AOR) Toolkit and the CoreTrustSeal ${ }^{5}$. This wealth of existing work has provided reference points to ensure broad coverage for assessment of digital preservation capability. The model has been developed, tested and refined with input from DPC Members including those who make up the Research and Practice Sub-Committee. Particular thanks go to

\footnotetext{
${ }^{1}$ Definition adapted from the Digital Preservation Handbook: https://www.dpconline.org/handbook/glossary\#D

${ }^{2}$ Brown, A (2013) Practical Digital Preservation: a how-to guide for organizations of any size, Facet Publishing: London

${ }^{3}$ https://ndsa.org/activities/levels-of-digital-preservation/

${ }^{4}$ https://www.securelyrooted.com/dpcmm

${ }^{5}$ https://www.coretrustseal.org/
} 
Adrian Brown for providing a starting point for this model and his support in taking this forward. Initial work on this model was carried out as part of a collaborative digital preservation project funded by the Nuclear Decommissioning Authority.

Version two of DPC RAM was released in March 2021. Revisions to the model were made in response to community feedback and evolving digital preservation good practice. Special thanks go to Hervé L'Hours and Simon Wilson for their detailed feedback and to the DPC's Research and Practice Sub-Committee and Adrian Brown for reviewing the proposed changes.

\section{Guiding Principles}

Many of the existing maturity models target particular domains (e.g. data repositories as in the CoreTrustSeal), limit their scope to a specific subset of preservation considerations (e.g. primarily technical in the NDSA Levels) or champion particular preservation approaches (e.g. migration-based approaches and open file formats in DPCMM).

The DPC membership is diverse, ranging from the GLAM sector to finance, science, manufacturing and beyond. For organizations across the Coalition to be able to usefully benchmark, compare and contrast their maturity it was necessary to develop a model which could be applied in different kinds of organizations, regardless of their mission, scale and approach. The maturity levels are based on existing good practice and try to be agnostic to particular preservation strategies or approaches. Organizations should find it easy to use the model to assess where they are now and consider where they would like to be in the future.

This model aims to be:

- Applicable for organizations of any size and in any sector

- Applicable for all content of long-term value

- Preservation strategy and solution agnostic

- Based on existing good practice

- Simple to understand and quick to apply

\section{How to Use This Model}

This model should be used as a rapid benchmarking tool, enabling a quick and simple assessment which can be applied frequently with minimal effort and consultation across an organization ${ }^{6}$. It is expressly not a strict and comprehensive certification tool that might provide a "deep dive" assessment.

A guiding statement is supplied for each criteria level. For criteria levels 2 to 4 , bulleted lists of examples are also supplied. It is important to note that the bulleted lists within each criteria level are provided as illustrative examples, not a checklist of requirements that must be met before the respective level is attained. An

\footnotetext{
${ }^{6}$ Early testing of the model suggests that the basic assessment can be carried out in less than two hours by someone with good knowledge of digital preservation and how it is applied in their own organization. For others it may take longer, particularly if multiple stakeholders need to be consulted. Setting future goals and priorities is likely to be a longer process.
} 
organization using the tool should consider which level best fits its current capability. This should be an honest and realistic assessment on the level closest to its current state. Where an organization partially meets a level but feels that more work is required in order to sit comfortably within that level, the score awarded should be the level below. No half marks are given!

An organization should then consider which level they would like to achieve in the future. Setting a target level will increase understanding of gaps and priorities for moving forward. It is important to note that not every organization needs to strive to reach an optimized level for each section of DPC RAM. For some organizations it may be appropriate to aim for a basic or managed level for one or more sections. A target is most useful if it is realistic and set with a clear understanding of organizational context and priorities. The time frame used for these target levels should be noted - for some organizations short term targets to be completed in the next 12 months will be appropriate, others may find it more helpful to consider where they would like to be in five or ten years' time.

A worksheet sits alongside this model which allows organizations to record the following:

- The current maturity level for each of the criteria

- Notes on/evidence of why this level has been selected

- The level of maturity the organization wishes to achieve

- Notes on the target level, specifically, what needs to be done to achieve it

This worksheet can be found at the end of this document and is also available as an Excel spreadsheet which produces visualizations of results. ${ }^{7}$

\section{Benefits of Use}

By applying this model, an organization will be able to produce evidence-based data on their capacity and maturity over time, as well as being able to answer questions such as:

- Where is our organization now?

- Are there any gaps in our organization's preservation capabilities?

- Where would we like to be in the future?

- How close is our organization to reaching the level of preservation maturity we would like?

- What should the priorities be for improving our organization's preservation capability?

- What support and resources do we need in order to help our organization move forward?

- How has our organization's capability improved over time?

\section{Benefits for DPC Members}

DPC RAM has been developed as a core DPC Member benefit in order to:

\footnotetext{
7 This digital worksheet in Excel format can be downloaded from the DPC RAM website: https://www.dpconline.org/digipres/implement-digipres/dpc-ram
} 
- Target member support activities for full members, allowing rapid assessment of current capabilities and highlighting areas where support will be most beneficial.

- Facilitate the sharing of information on maturity levels, allowing organizations to compare their status with results across the DPC or to similar DPC Member organizations.

- Help the DPC to better understand their membership as a whole and use this information to shape ongoing programs of research, training, and resource development in line with member priorities.

The DPC will provide members with an online form for entering information on maturity levels on an annual basis. The form will allow members to specify preferences on how the data is used and shared. The DPC will send members a copy of their responses for reference and will collate and analyse this information and report trends and patterns back to members. The DPC may use the data (with permission) to make connections between DPC Members. This model will further support interactions between DPC staff and Coalition Members, and will be a key tool in facilitating member support activities.

In addition to benefits available to all as listed in the previous section, the DPC RAM will allow DPC Members to answer the following questions:

- How does my organization's digital preservation maturity compare with that of the wider DPC membership?

- How does my organization's digital preservation maturity compare with that of similar institutions within the DPC?

- Where would we most benefit from DPC support?

- What DPC resources do we need in order to progress?

\section{Explanation of Terms}

The term 'Digital Archive' is used throughout the DPC RAM to refer to a facility where content in digital form with enduring value is stored and managed for long term preservation.

The term 'Organization' is used through the DPC RAM to refer to the unit of an organization that is being measured. Typically, this will be a specific section of an organization that has a remit to manage and preserve digital content, but in some instances it may be appropriate to look at the organization as a whole. Each body using this model will need to establish first which part of their organization they are measuring. There is no one correct way of approaching this and users of this model are encouraged to define organizational scope in the way that best meets their own needs.

\section{Note on Scope}

This model specifically excludes IT security issues. Whilst considered extremely important from a capability and resilience standpoint, it is an area that is already well-served by existing IT security guidance (for example the ISO/IEC 27000 family 
of standards ${ }^{8}$ ). It was also felt that the results of an assessment against such criteria could in itself be sensitive or confidential.

\section{Comments, Feedback and Revisions}

While digital preservation activities have been occurring in many organizations for two decades, the discipline as a whole will continue to change and develop in response to external drivers and fresh challenges. New solutions, ways of working and examples of good practice will emerge. For this model to be useful for demonstrating progress, we anticipate that the basic premise of each of the maturity levels will remain the same. However, the examples within each section may be updated and enhanced over time in line with developments in the field and in response to feedback from DPC Members and the wider digital preservation community. If you have any suggestions for updates or additions, please use the feedback form which is available from the DPC RAM website ${ }^{9}$.

8 https://www.iso.org/isoiec-27001-information-security.html

9 https://forms.gle/qDhxsnYoVMaYbtki6 


\section{The Model}

There are 11 sections of DPC RAM covering different elements of digital preservation capability that are grouped into two parts. Organizational capabilities are defined at an organizational or other appropriate high level of granularity. Service capabilities refer to operational levels that might be considered at a lower level of granularity, possibly specific to a particular content stream.

\begin{tabular}{|c|c|c|}
\hline \multicolumn{3}{|c|}{ Organizational capabilities } \\
\hline A & $\frac{\text { Organizational }}{\text { viability }}$ & $\begin{array}{l}\text { Governance, organizational structure, staffing and resourcing of } \\
\text { digital preservation activities. }\end{array}$ \\
\hline B & $\frac{\text { Policy and }}{\text { strategy }}$ & $\begin{array}{l}\text { Policies, strategies, and procedures which govern the operation } \\
\text { and management of the digital archive. }\end{array}$ \\
\hline C & Legal basis & $\begin{array}{l}\text { Management of legal rights and responsibilities, compliance with } \\
\text { relevant regulation and adherence to ethical codes related to } \\
\text { acquiring, preserving and providing access to digital content. }\end{array}$ \\
\hline $\mathrm{D}$ & IT capability & $\begin{array}{l}\text { Information Technology capabilities for supporting digital } \\
\text { preservation activities. }\end{array}$ \\
\hline$E$ & $\frac{\text { Continuous }}{\text { improvement }}$ & $\begin{array}{l}\text { Processes for the assessment of current digital preservation } \\
\text { capabilities, the definition of goals and the monitoring of progress. }\end{array}$ \\
\hline $\mathrm{F}$ & Community & $\begin{array}{l}\text { Engagement with and contribution to the wider digital preservation } \\
\text { community. }\end{array}$ \\
\hline \multicolumn{3}{|c|}{ Service capabilities } \\
\hline G & $\begin{array}{l}\frac{\text { Acquisition, }}{\text { transfer and }} \\
\underline{\text { ingest }}\end{array}$ & $\begin{array}{l}\text { Processes to acquire or transfer content and ingest it into a digital } \\
\text { archive. }\end{array}$ \\
\hline $\mathrm{H}$ & $\frac{\text { Bitstream }}{\text { preservation }}$ & $\begin{array}{l}\text { Processes to ensure the storage and integrity of digital content to } \\
\text { be preserved. }\end{array}$ \\
\hline 1 & $\frac{\text { Content }}{\text { preservation }}$ & $\begin{array}{l}\text { Processes to preserve the meaning or functionality of the digital } \\
\text { content and ensure its continued accessibility and usability over } \\
\text { time. }\end{array}$ \\
\hline J & $\frac{\text { Metadata }}{\text { management }}$ & $\begin{array}{l}\text { Processes to create and maintain sufficient metadata to support } \\
\text { preservation, discovery and use of preserved digital content. }\end{array}$ \\
\hline K & $\begin{array}{l}\text { Discovery and } \\
\text { access }\end{array}$ & $\begin{array}{l}\text { Processes to enable discovery of digital content and provide } \\
\text { access for users. }\end{array}$ \\
\hline
\end{tabular}




\section{Organizational capabilities}

\section{A - Organizational viability}

Governance, organizational structure, staffing and resourcing of digital preservation activities.

0 - Minimal awareness

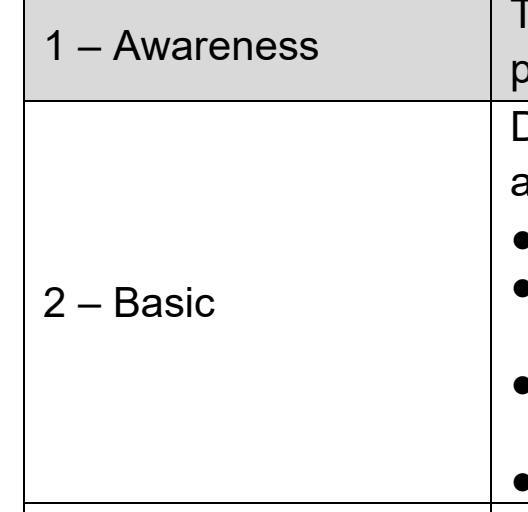

The organization has minimal awareness of the need to support digital preservation activities.

The organization is aware of the need to support digital preservation activities

Digital preservation activities are supported and resourced at a basic level within the organization, for example:

- There is some engagement from senior management.

- Staff have assigned responsibilities and the time to undertake them.

- A budget for digital preservation has been allocated (may be time-limited).

- Staff development requirements have been identified.

Digital preservation activities are managed and supported within the organization, for example:

- There is commitment from senior management.

- Responsibility for digital preservation is clearly owned.

- Staff have the skills they need to carry out digital preservation activities and access to relevant expertise where required.

- A dedicated core budget for digital preservation has been allocated.

- Budgets, staff roles and development needs are regularly assessed.

- Metrics and reports can be generated about the digital archive to help inform reporting, planning and management.

- Staff development requirements have been funded.

- Digital preservation has been identified as a strategic priority.

Digital preservation activities are proactively managed, enhanced and developed within the organization, for example:

- Benefits of digital preservation are recognized, championed and embedded throughout the organization.

- A cross-departmental digital preservation stakeholder group has been established.

- One or more staff are considered to be experts in their field. 


\begin{tabular}{|l|l|}
\hline$\bullet \begin{array}{l}\text { Budgets, staff roles and development needs are } \\
\text { proactively assessed in anticipation of future changes. } \\
\text { - Metrics and reports about the digital archive are } \\
\text { combined with projections of future needs to proactively } \\
\text { inform reporting, planning and management. }\end{array}$ \\
- The efficacy of staff development is regularly monitored. \\
$\begin{array}{l}\text { Continuity and succession plans are in place to ensure } \\
\text { ongoing preservation of holdings if the organization can } \\
\text { no longer carry out these activities. }\end{array}$ \\
\hline
\end{tabular}




\section{B - Policy and strategy}

Policies, strategies, and procedures which govern the operation and management of the digital archive.

\begin{tabular}{|l|l|}
\hline 0 - Minimal awareness & $\begin{array}{l}\text { The organization has minimal awareness of the need for a } \\
\text { policy framework for digital preservation. }\end{array}$ \\
\hline $1-$ Awareness & $\begin{array}{l}\text { The organization is aware of the need to develop a policy } \\
\text { framework and may have some relevant policies but no } \\
\text { digital preservation policy or strategy exists. }\end{array}$ \\
\hline & $\begin{array}{l}\text { The organization has a basic policy framework, for } \\
\text { example: }\end{array}$
\end{tabular}

- A high-level digital preservation policy or strategy exists.

- Other policies relating to digital preservation may exist but there are gaps in coverage.

2 - Basic

- Some procedures for managing, and providing access to, digital content are in place and may be documented.

- Scope of collection is defined and understood (eg: collections development policy, retention schedule).

- Development of policy and procedure is informed by a basic understanding of user needs.

The organization has a comprehensive and managed suite of policies, strategies and procedures, for example:

- The digital preservation policy/strategy is aligned with other organizational policies and is reviewed according to an agreed schedule.

- Policy and procedure takes into account any relevant ethical issues.

3 - Managed

- A suite of documented processes and procedures for managing, and providing access to, content within the digital archive exists.

- All relevant staff are aware of digital preservation policies, strategies and procedures.

- Knowledge of current and future use cases for content informs policy and procedure (for example on collecting, preservation approaches, metadata and access).

The organization proactively manages its policies, strategies and procedures and has a commitment to continuous process improvement, for example:

- A full suite of policies, strategies and procedures 4 - Optimized relating to the preservation of, and access to, digital content is in place

- Policy and strategy is fully implemented and staff actively engage with it.

- Policy, strategy and procedure is proactively monitored and updated to reflect internal changes, changes in other policies, user needs, or other external factors. 


\section{C - Legal basis}

Management of legal rights and responsibilities, compliance with relevant regulation and adherence to ethical codes related to acquiring, preserving and providing access to digital content.

\begin{tabular}{|c|c|}
\hline 0 - Minimal awareness & $\begin{array}{l}\text { The organization has minimal awareness of either the need } \\
\text { to manage legal rights and responsibilities or basic } \\
\text { principles for applying them. }\end{array}$ \\
\hline 1 - Awareness & $\begin{array}{l}\text { The organization is aware of the need to manage legal } \\
\text { rights and responsibilities and an understanding of basic } \\
\text { principles. }\end{array}$ \\
\hline 2 - Basic & $\begin{array}{l}\text { Basic management of legal rights and responsibilities } \\
\text { relating to digital content is carried out, for example: } \\
\text { - Key legal rights and responsibilities, together with their } \\
\text { owners, have been identified and documented. } \\
\text { - Templates exist for necessary legal agreements and } \\
\text { licences. } \\
\text { - Relevant codes of conduct relating to professional } \\
\text { ethics are adhered to. }\end{array}$ \\
\hline 3-Managed & $\begin{array}{l}\text { Legal rights and responsibilities relating to digital content } \\
\text { are managed, for example: } \\
\text { - Information relating to licensing, legal rights and } \\
\text { contracts can be easily located and accessed when } \\
\text { necessary. } \\
\text { - Legal issues and risks are managed and regularly } \\
\text { reviewed. } \\
\text { - Roles and responsibilities for managing legal issues and } \\
\text { risks are clearly assigned. } \\
\text { - Expert advice can be accessed when necessary (for } \\
\text { example from legal, procurement, contract management } \\
\text { or information compliance specialists). } \\
\text { - Actions carried out due to legal rights and } \\
\text { responsibilities are documented. } \\
\text { - Different preservation or access workflows are in place } \\
\text { for content with differing legal or regulatory } \\
\text { requirements. } \\
\text { - Accessibility responsibilities are fulfilled, in line with the } \\
\text { requirements of relevant local or national legislation. }\end{array}$ \\
\hline 4 - Optimized & $\begin{array}{l}\text { Legal rights and responsibilities relating to digital content } \\
\text { are proactively managed, for example: } \\
\text { - Legal issues and risks are proactively monitored and } \\
\text { mitigated. } \\
\text { - The organization engages with and inputs into legal and } \\
\text { judicial processes that create regulation. }\end{array}$ \\
\hline
\end{tabular}




\begin{tabular}{|c|c|}
\hline \multicolumn{2}{|l|}{$\begin{array}{l}\text { D - IT capability } \\
\text { Information Technol }\end{array}$} \\
\hline 0 - Minimal awareness & $\begin{array}{l}\text { The organization has minimal awareness of either the need } \\
\text { for IT capability to support the digital archive or basic } \\
\text { principles for applying it. }\end{array}$ \\
\hline 1 - Awareness & $\begin{array}{l}\text { The organization is aware of the need for IT capability to } \\
\text { support the digital archive, and has an understanding of } \\
\text { basic principles. }\end{array}$ \\
\hline 2 - Basic & $\begin{array}{l}\text { The organization has access to basic IT facilities including } \\
\text { technical infrastructure and support, for example: } \\
\text { - Basic IT support is available to the digital archive. } \\
\text { - Staff with IT responsibilities have a basic understanding } \\
\text { of their role in supporting digital preservation. } \\
\text { - IT systems are documented at a basic level. }\end{array}$ \\
\hline 3 - Managed & $\begin{array}{l}\text { The organization has access to comprehensively managed } \\
\text { IT facilities including technical infrastructure and support, } \\
\text { for example: } \\
\text { - Adequate IT support is available to the digital archive. } \\
\text { - IT roles and responsibilities relating to digital } \\
\text { preservation are documented and regularly reviewed. } \\
\text { - IT systems are regularly patched and updated. } \\
\text { - New tools and systems are deployed when required. } \\
\text { - IT systems are comprehensively documented. } \\
\text { - Contracts and services with third party service providers } \\
\text { (e.g. cloud suppliers) are well managed and } \\
\text { documented. }\end{array}$ \\
\hline 4 - Optimized & $\begin{array}{l}\text { The organization has access to proactively managed IT } \\
\text { facilities that are continually evolving and improving, for } \\
\text { example: } \\
\text { - An enhanced level of IT support is available to the } \\
\text { digital archive } \\
\text { - IT demonstrates good understanding of, and } \\
\text { engagement with, digital preservation issues. } \\
\text { - Digital preservation requirements are taken into account } \\
\text { when sourcing new IT systems. } \\
\text { - A detailed roadmap exists for future development of IT } \\
\text { systems. } \\
\text { - Potential new tools and systems are proactively } \\
\text { identified and tested. }\end{array}$ \\
\hline
\end{tabular}




\begin{tabular}{|c|c|}
\hline \multicolumn{2}{|c|}{$\begin{array}{l}\text { E - Continuous improvement } \\
\text { Processes for the assessment of current digital preservation capabilities, the } \\
\text { definition of goals and the monitoring of progress. }\end{array}$} \\
\hline 0 - Minimal awareness & $\begin{array}{l}\text { The organization has minimal awareness of current position } \\
\text { or goals. }\end{array}$ \\
\hline 1 - Awareness & $\begin{array}{l}\text { The organization is aware of the need to understand } \\
\text { current position and define goals. }\end{array}$ \\
\hline 2 - Basic & $\begin{array}{l}\text { The organization has a basic understanding of current } \\
\text { digital preservation capabilities and areas for improvement, } \\
\text { for example: } \\
\text { - An initial benchmarking exercise has been carried out. } \\
\text { - Gaps in digital preservation capability have been } \\
\text { identified. } \\
\text { - There is an understanding of where the organization is } \\
\text { relative to peers. }\end{array}$ \\
\hline 3 - Managed & $\begin{array}{l}\text { The organization has a managed process for } \\
\text { benchmarking and establishing goals, for example: } \\
\text { - Goals have been established and agreed with senior } \\
\text { managers. } \\
\text { - Roadmap is in place to reach goals. } \\
\text { - Benchmarking exercise is repeated periodically. }\end{array}$ \\
\hline 4 - Optimized & $\begin{array}{l}\text { The organization undertakes continuous process } \\
\text { improvement, with proactive management, for example: } \\
\text { - Certification/external review has been achieved and is } \\
\text { maintained as appropriate. } \\
\text { - Recommendations for improvement have been acted } \\
\text { upon. } \\
\text { - Goals and roadmap are reviewed periodically. }\end{array}$ \\
\hline
\end{tabular}




\section{F - Community}

Engagement with and contribution to the wider digital preservation community.

\begin{tabular}{|l|l|}
\hline 0 - Minimal awareness & $\begin{array}{l}\text { The organization has minimal awareness of the need to } \\
\text { engage with the wider digital preservation community. } \\
\text { The organization is aware of the benefits of collaboration } \\
\text { with the wider digital preservation community. }\end{array}$ \\
\hline 2- Awareness & $\begin{array}{l}\text { The organization engages with the wider digital } \\
\text { preservation community at a basic level, for example: } \\
\text { - Network/s of relevant contacts have been established. } \\
\text { - Relevant community events can be accessed. } \\
\text { - There is commitment to learn from the experiences of } \\
\text { others. }\end{array}$ \\
\hline $3-$ Managed & $\begin{array}{l}\text { Engagement with the wider digital preservation community } \\
\text { is supported and managed, for example: } \\
\text { - Relevant networks and communities have been joined. } \\
\text { - An active role is taken in the digital preservation } \\
\text { community. } \\
\text { Expert advice on digital preservation can be accessed } \\
\text { as appropriate. } \\
\text { - Successes and lessons learned from own work is } \\
\text { shared with the community. }\end{array}$ \\
\hline $4-$ Optimized & $\begin{array}{l}\text { The organization takes a leadership role in the digital } \\
\text { preservation community and proactively manages these } \\
\text { engagements, for example: } \\
\text { A proactive role is taken in establishing or organizing } \\
\text { community networks, collaborative activities or events. } \\
\text { Contributions are made to expert groups, committees or } \\
\text { task forces. }\end{array}$ \\
\hline
\end{tabular}




\section{Service capabilities}

\section{G - Acquisition, transfer and ingest}

Processes to acquire or transfer content and ingest it into a digital archive.

\begin{tabular}{|c|c|}
\hline 0 - Minimal awareness & $\begin{array}{l}\text { The organization has minimal awareness of either the need } \\
\text { to acquire or transfer digital content to a digital archive or } \\
\text { basic principles for doing so. }\end{array}$ \\
\hline 1 - Awareness & $\begin{array}{l}\text { The organization is aware of the need to acquire or transfer } \\
\text { digital content into a digital archive, and has an } \\
\text { understanding of basic principles of ingest. }\end{array}$ \\
\hline 2 - Basic & $\begin{array}{l}\text { The organization has implemented a basic process for } \\
\text { acquisition, transfer and ingest, for example: } \\
\text { - A documented ingest process exists. } \\
\text { - Basic guidance for donors, depositors and record } \\
\text { creators is available where appropriate. } \\
\text { - Documentation and metadata is sometimes received or } \\
\text { captured as part of the acquisition or transfer process. } \\
\text { - A documented process exists for selecting and } \\
\text { capturing digital content where appropriate (for example } \\
\text { for web archives, email archives, digitized content, } \\
\text { records within an EDRMS) } \\
\text { - Some content is appraised as part of a manual process } \\
\text { in line with relevant policies. } \\
\text { - A working area (physical or virtual) is available for pre- } \\
\text { ingest and ingest activities (for example to carry out } \\
\text { virus checking and file identification). }\end{array}$ \\
\hline 3-Managed & $\begin{array}{l}\text { The organization has implemented a comprehensive, } \\
\text { managed process for acquisition, transfer and ingest, for } \\
\text { example: } \\
\text { - Relationships with donors, depositors and record } \\
\text { creators are managed through ongoing communication, } \\
\text { guidance, and support where required. } \\
\text { - Appraisal is a standard part of the ingest workflow. } \\
\text { - Workflows are efficient and fit for purpose. } \\
\text { - Parts of the ingest process are automated. } \\
\text { - Successful transfer of content is verified by integrity } \\
\text { checking. }\end{array}$ \\
\hline 4 - Optimized & $\begin{array}{l}\text { The organization proactively manages and improves the } \\
\text { acquisition, transfer and ingest process, for example: } \\
\text { - The organization coordinates with potential donors, } \\
\text { depositors and record creators to support best practice } \\
\text { lifecycle management. } \\
\text { - Internal IT systems that create and hold digital content } \\
\text { which will be transferred to the archive, are procured }\end{array}$ \\
\hline
\end{tabular}




\begin{tabular}{|l|l|}
\hline and configured with an awareness of requirements for \\
future preservation. \\
- The ingest process is automated where it is beneficial to \\
do so, with the ability to make manual interventions \\
where necessary. \\
- Tools and systems in use have been fully integrated. \\
- Software tools are applied to automate and enhance the \\
process, for example highlighting sensitive information \\
or informing appraisal decisions. \\
Reappraisal is carried out periodically, taking into \\
account factors such as value of content, use metrics, \\
and costs of preservation (both financial and \\
environmental).
\end{tabular}




\section{H - Bitstream preservation}

Processes to ensure the storage and integrity of digital content to be preserved.

\begin{tabular}{|c|c|}
\hline 0 - Minimal awareness & $\begin{array}{l}\text { The organization has minimal awareness of either the need } \\
\text { for bitstream preservation or basic principles for applying it. }\end{array}$ \\
\hline 1 - Awareness & $\begin{array}{l}\text { The organization is aware of the need for bitstream } \\
\text { preservation, and has an understanding of basic principles. }\end{array}$ \\
\hline 2 - Basic & $\begin{array}{l}\text { The organization has implemented a basic process for } \\
\text { bitstream preservation, for example: } \\
\text { - Dedicated storage is available to meet current } \\
\text { preservation needs. } \\
\text { - Staff know where content is stored. } \\
\text { - Replication is based on simple backup regimes. } \\
\text { - Checksums are generated for all content. } \\
\text { - There is an understanding of which staff members } \\
\text { should be authorized to access the content. }\end{array}$ \\
\hline 3 - Managed & $\begin{array}{l}\text { The organization stores content in a managed way } \\
\text { consistent with preservation good practice for replication } \\
\text { and integrity checking. For example: } \\
\text { - Content is managed with a combination of integrity } \\
\text { checking and content replication to one or more } \\
\text { locations. } \\
\text { - Decisions on the frequency of integrity checking and the } \\
\text { number of copies held take into consideration risks, } \\
\text { value of the content and costs (both financial and } \\
\text { environmental). } \\
\text { - Content failing integrity checks is repaired. } \\
\text { - Authorizations to access the content by staff are } \\
\text { enforced and documented. } \\
\text { - Tests are routinely carried out to verify the effectiveness } \\
\text { of backups, replication and integrity checking. }\end{array}$ \\
\hline 4 - Optimized & $\begin{array}{l}\text { The organization applies a highly managed storage regime } \\
\text { with proactive risk management, for example: } \\
\text { - Geographically separated copies are held to minimise } \\
\text { the risk of loss due to disaster. } \\
\text { - Different storage technologies or services are in use. } \\
\text { - Future storage needs are regularly predicted and } \\
\text { updated and storage capacity is monitored and revised } \\
\text { accordingly. } \\
\text { - Content integrity and processes to ascertain integrity } \\
\text { are independently reviewed } \\
\text { - All access to content is logged and reviewed for } \\
\text { unauthorized use and/or changes made: which content, } \\
\text { when and by whom. }\end{array}$ \\
\hline
\end{tabular}




\section{I - Content preservation}

Processes to preserve the meaning or functionality of the digital content and ensure its continued accessibility and usability over time.

\begin{tabular}{|c|c|}
\hline 0 - Minimal awareness & $\begin{array}{l}\text { The organization has minimal awareness of either the need } \\
\text { for content preservation or basic principles for applying it. }\end{array}$ \\
\hline 1 - Awareness & $\begin{array}{l}\text { The organization is aware of the need for content } \\
\text { preservation, and has an understanding of basic principles. }\end{array}$ \\
\hline 2 - Basic & $\begin{array}{l}\text { The organization has implemented a basic process to } \\
\text { understand the content that they hold, for example: } \\
\text { - File formats are identified. } \\
\text { - Content is characterized and assessed for preservation } \\
\text { and quality issues such as encrypted, broken or } \\
\text { incomplete content and invalid files. } \\
\text { - There is a basic understanding of current and future } \\
\text { users and use cases for the content. }\end{array}$ \\
\hline 3 - Managed & $\begin{array}{l}\text { The organization has implemented a managed process to } \\
\text { monitor and plan for accessibility of content over time, for } \\
\text { example: } \\
\text { - Technology watch activities are carried out and 'at risk' } \\
\text { content is identified. } \\
\text { - Technical dependencies are detected and documented. } \\
\text { - Actions are occasionally carried out to ensure } \\
\text { preservation and quality of content such as migration, } \\
\text { emulation or modification of creation or capture } \\
\text { workflows. } \\
\text { - Preservation actions occur with an understanding of the } \\
\text { properties of the digital object that should be retained to } \\
\text { support current and future use cases. } \\
\text { - All changes to digital content are recorded, including } \\
\text { details of when, what, how, why and who. }\end{array}$ \\
\hline 4 - Optimized & $\begin{array}{l}\text { The organization takes a proactive approach to prioritize } \\
\text { and mitigate preservation risks to ensure content is } \\
\text { accessible over time, for example: } \\
\text { - Risks to specific file formats or types of content held are } \\
\text { well understood. } \\
\text { - A rigorous preservation planning process identifies } \\
\text { appropriate preservation actions for risk mitigation. } \\
\text { - Decisions on whether to enact preservation actions take } \\
\text { into account risks, value of content, costs (both financial } \\
\text { and environmental) and use cases. } \\
\text { - Format migrations, normalizations, emulation and other } \\
\text { preservation actions are implemented in accordance } \\
\text { with preservation plans. } \\
\text { - Quality control is in place to assess (and record) the } \\
\text { outcome of preservation actions, ensuring that the }\end{array}$ \\
\hline
\end{tabular}


Digital Preservation Coalition Rapid Assessment Model (version 2 - March 2021) DOI: http://doi.org/10.7207/dpcram21-02

\begin{tabular}{|l|l|}
\hline & $\begin{array}{l}\text { meaning and/or functionality of the content has been } \\
\text { retained as required. } \\
\text { Digital content and metadata are version controlled } \\
\text { where appropriate. }\end{array}$ \\
\hline
\end{tabular}




\section{J - Metadata management}

Processes to create and maintain sufficient metadata to support preservation, discovery and use of preserved digital content.

\begin{tabular}{|l|l|}
\hline 0 - Minimal awareness & $\begin{array}{l}\text { The organization has minimal awareness of either the need } \\
\text { to manage metadata or basic principles for implementing it. }\end{array}$ \\
\hline 1- Awareness & $\begin{array}{l}\text { The organization is aware of the need to manage } \\
\text { metadata, and has an understanding of basic principles. }\end{array}$ \\
\hline The organization creates and maintains metadata for \\
preservation, discovery and use at a basic level, for \\
example: \\
- Basic
\end{tabular}




\section{$\mathrm{K}$ - Discovery and access}

Processes to enable discovery of digital content and provide access for users.

\begin{tabular}{|l|l|}
\hline 0 - Minimal awareness & $\begin{array}{l}\text { The organization has minimal awareness of either the need } \\
\text { to enable discovery and access for their user community or } \\
\text { basic principles for carrying this out }\end{array}$ \\
\hline 1- Awareness & $\begin{array}{l}\text { The organization is aware of the need to enable discovery } \\
\text { and access for their user community, and has an } \\
\text { understanding of basic principles. }\end{array}$ \\
\hline The organization has implemented a basic discovery and \\
access mechanism (where access rights permit), for \\
example: \\
- Basic
\end{tabular}


- Information collected about discovery and access to digital content is used to improve and enhance the user experience.

- Digital content is available to users in accessible formats.

- Access mechanisms are compatible with, or integrate common accessibility tools. 


\section{Appendix I - DPC RAM worksheet}

\begin{tabular}{|r|r|}
\hline Organization: & \\
\hline Assessment completed by: & \\
\hline Assessment complete on: & \\
\hline Notes on scope of assessment \\
(type of content or department):
\end{tabular}

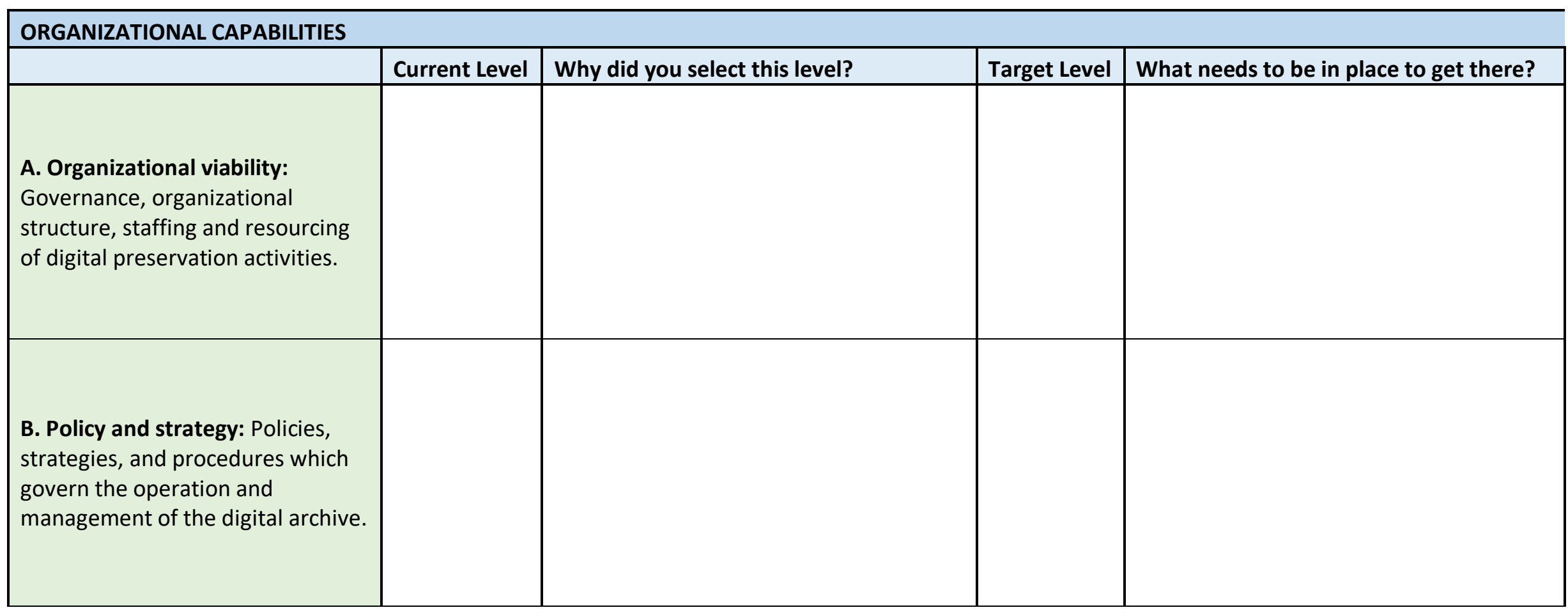


Digital Preservation Coalition Rapid Assessment Model (version 2 - March 2021) DOI: http://doi.org/10.7207/dpcram21-02

\begin{tabular}{|c|c|c|c|c|}
\hline & Current Level & Why did you select this level? & Target Level & What needs to be in place to get there? \\
\hline $\begin{array}{l}\text { C. Legal basis: Management of } \\
\text { legal rights and responsibilities, } \\
\text { compliance with relevant } \\
\text { regulation and adherence to } \\
\text { ethical codes related to acquiring, } \\
\text { preserving and providing access to } \\
\text { digital content. }\end{array}$ & & & & \\
\hline $\begin{array}{l}\text { D. IT capability: Information } \\
\text { Technology capabilities for } \\
\text { supporting digital preservation } \\
\text { activities. }\end{array}$ & & & & \\
\hline $\begin{array}{l}\text { E. Continuous Improvement: } \\
\text { Processes for the assessment of } \\
\text { current digital preservation } \\
\text { capabilities, the definition of goals } \\
\text { and the monitoring of progress. }\end{array}$ & & & & \\
\hline $\begin{array}{l}\text { F. Community: Engagement with } \\
\text { and contribution to the wider } \\
\text { digital preservation community. }\end{array}$ & & & & \\
\hline
\end{tabular}


Digital Preservation Coalition Rapid Assessment Model (version 2 - March 2021)

DOI: http://doi.org/10.7207/dpcram21-02

\section{SERVICE CAPABILITIES}

\begin{tabular}{|c|c|c|c|c|}
\hline & Current Level & Why did you select this level? & Target Level & What needs to be in place to get there? \\
\hline $\begin{array}{l}\text { G. Acquisition, Transfer and } \\
\text { Ingest: Processes to acquire or } \\
\text { transfer content and ingest it into } \\
\text { a digital archive. }\end{array}$ & & & & \\
\hline $\begin{array}{l}\text { H. Bitstream Preservation: } \\
\text { Processes to ensure the storage } \\
\text { and integrity of digital content to } \\
\text { be preserved. }\end{array}$ & & & & \\
\hline $\begin{array}{l}\text { I. Content Preservation: Processes } \\
\text { to preserve the meaning or } \\
\text { functionality of the digital content } \\
\text { and ensure its continued } \\
\text { accessibility and usability over } \\
\text { time. }\end{array}$ & & & & \\
\hline
\end{tabular}


Digital Preservation Coalition Rapid Assessment Model (version 2 - March 2021)

DOI: http://doi.org/10.7207/dpcram21-02

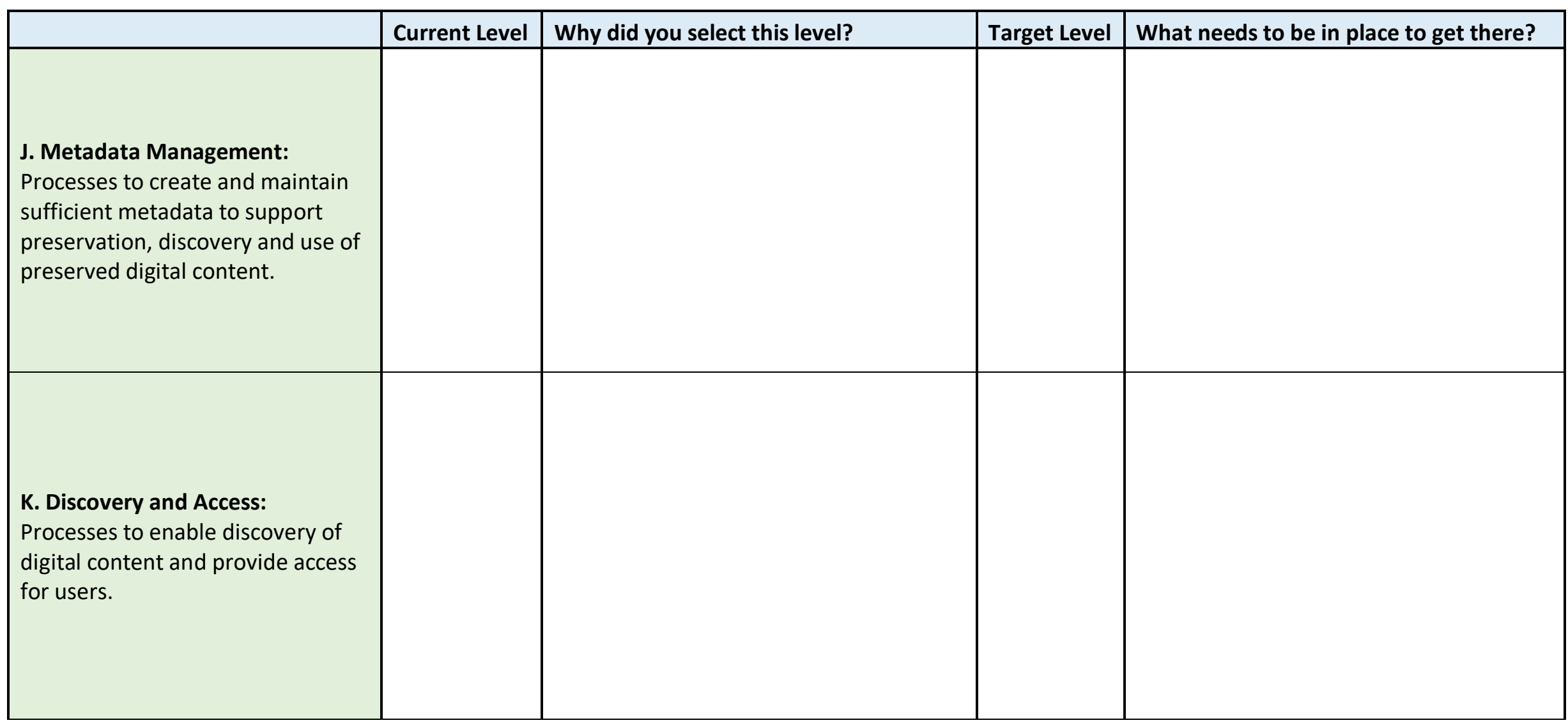

